\title{
Endocrine Changes after Mating in Pregnant and Non-Pregnant Llamas and Alpacas
}

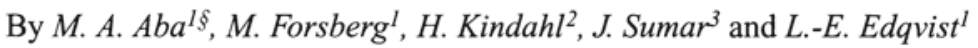 \\ ${ }^{1}$ Department of Clinical Chemistry, and ${ }^{2}$ Department of Obstetrics and Gynaecology, Faculty of Veterinary Me- \\ dicine, Swedish University of Agricultural Sciences, Uppsala, Sweden, and ${ }^{3}$ Instituto Veterinario de Investiga- \\ ciones Tropicales de Altura, Universidad Mayor de San Marcos, Lima, Perú.
}

\begin{abstract}
Aba, M. A., M. Forsberg, H. Kindahl, J. Sumar and L.-E. Edqvist: Endocrine changes after mating in pregnant and non-pregnant llamas and alpacas. Acta vet. scand. 1995, 36, 489-498. - Plasma concentrations of oestradiol-17ß, progesterone, 15keto-dihydro-PGF ${ }_{2 \alpha}$ and luteinizing hormone $(\mathrm{LH})$ were monitored in llamas and alpacas after mating with an intact male. Concentrations of $\mathrm{LH}$ and $\mathrm{PGF}_{2 \alpha}$ metabolite were high immediately after copulation. Ovulation occurred in $92 \%$ of the animals. The first significant increases in progesterone were recorded on day 4 after mating. In non-pregnant animals the lifespan of the corpus luteum was estimated to be 8-9 days. Luteolysis occurred in association with the release of $\mathrm{PGF}_{2 \alpha}$. In pregnant animals, a transient decrease in progesterone concentrations was observed between days 8 and 18 in both species. No significant changes in $\mathrm{PGF}_{2 \alpha}$ secretion were registered during this period. Oestradiol-17B concentrations were high on the day of mating, declined to low values on day 4 , and started to increase again on day 8 . Peak values after luteolysis in non-pregnant animals were significantly higher than those registered in pregnant ones. Furthermore, concentrations of oestradiol-17ß were elevated for a longer period in non-pregnant than in pregnant animals. The results suggest that progesterone from the corpus luteum exerts a negative influence on follicular activity in pregnant animals by reducing oestradiol-17ß secretion.
\end{abstract}

oestradiol-17ß; prostaglandin $F_{2 a}$; early pregnancy.

\section{Introduction}

During the last decade, the reproductive physiology of the domesticated South American camelids, i.e. llamas (Lama glama) and alpacas (Lama pacos), has been under intense study. Both species are induced ovulators (Novoa 1970 ), and their prostaglandin and progesterone secretory profiles after mating and ovula-

\footnotetext{
$\S$ Permanent address:

Department of Physiopathology, Faculty of Veterinary Sciences, Universidad Nacional del Centro de la Provincia de Buenos Aires. Paraje Arroyo Seco, Tandil (7000), Buenos Aires, Argentina.
}

tion are well documented (Sumar et al. 1988, Leon et al. 1990).

As in many other mammals (Pierson \& Ginter 1987, Savio et al. 1988) follicular activity in llamas and alpacas is characterized by a wavelike pattern of follicular growth and regression (Adams et al. 1990). The follicular waves involve the synchronous emergence of several follicles, one of which becomes dominant and finally undergoes atresia unless copulation and ovulation occur, and the subsequent luteinization process is triggered. This process has been clearly shown using laparoscopy (Bravo \& Su- 
mar 1989, Pollard et al. 1994) and ultrasound techniques (Adams et al. 1990, Bravo et al. 1990a). However, few descriptions of oestradiol-17ß secretion and follicular development have been made, and the reported data are not in total agreement (Adams et al. 1990, Bravo et al. 1990a,b, Bravo et al. 1991a). Bravo et al. (1990a) registered a positive correlation between follicle size and plasma oestradiol-17ß concentrations in non-mated llamas. Although recruitment of new follicles starts immediately after mating and ovulation in llamas (Adams et al. 1990) and alpacas (Pollard et al. 1994), no changes in oestradiol-17ß concentrations have been observed during early pregnancy (Bravo et al. 1990b, Leon et al. 1990).

The aim of this study was to characterize the secretory profiles of oestradiol-17ß in relation to $\mathrm{LH}$, progesterone, and 15-keto-dihydro-prostaglandin $\mathrm{F}_{2 \alpha}$ secretion in pregnant and non-pregnant llamas and alpacas after mating with an intact male.

\section{Materials and methods Animals}

A total of 25 non-pregnant adult llamas (13) and alpacas (12) previously checked for normal reproductive function were kept in isolation from males until the beginning of the study. All animals were mated with intact males on day 0 . Laparoscopy 3 days after mating was used to determine whether ovulation had occurred. All animals ovulated except for 2 llamas which were, subsequently, excluded from the study. The animals were kept on natural pastures at the La Raya Research Station, Cuzco, Perú, located at $15^{\circ} \mathrm{S}, 70^{\circ} \mathrm{W}$, and $4200 \mathrm{~m}$ altitude. The study was carried out for 24 days in April (autumn). Blood samples were obtained on day 0 (immediately after mating), day 4 and daily from day 7 to day 14 after mating. Based on the progesterone profile on day 12 post-breeding, animals were classified as pregnant or non-pregnant.
Additional samples were obtained from days 15 to 19 and day 24 in all pregnant animals and from days 15 to 19 and days 23 and 24 in 2 nonpregnant llamas and alpacas. Blood was collected by jugular venipuncture into heparinized vacutainer tubes. Plasma was separated by centrifugation and stored at $-20^{\circ} \mathrm{C}$ until analyzed.

\section{Hormone assays}

Progesterone was assayed with an enhanced luminescence immunoassay technique (Amerli$t^{\mathrm{R}}$; Kodak Clinical Diagnostics Ltd., England) previously validated for canine plasma (Forsberg et al. 1993a). Serial dilutions of llama and alpaca plasma containing high concentrations of progesterone produced displacement curves parallel to the standard curve. The intra-assay coefficient of variation calculated from the precision profile of 5 assays was below $7 \%$ for concentrations between $2-160 \mathrm{nmol} \mathrm{l}^{-1}$. The inter-assay coefficients of variation for 3 quality control samples were $8 \%\left(2 \mathrm{nmol} \mathrm{l}^{-1}\right), 8 \%(18$ nmol $\left.1^{-1}\right)$ and $5 \%\left(54 \mathrm{nmol} \mathrm{l}^{-1}\right)$. The lowest amount of progesterone detectable (defined as intercept of maximal binding - 2 SD) was 0.2 nmol 1-1.

Oestradiol-17ß was determined using an RIA previously validated for use in bovine plasma (Sirois \& Fortune 1990) with the following modification: the standard curve was prepared with standards supplied with the Coat-A-Count radioimmunoassay kit (Diagnostic Products Corporation, Los Angeles, CA, USA). Serially diluted plasma from female llamas and alpacas containing high concentrations of oestradiol$17-\beta$ produced displacement curves parallel to the standard curve. The intra-assay coefficients of variation calculated from the precision profile of 7 assays were $13.4 \%$ at $6 \mathrm{pmol} \mathrm{l}^{-1}, 10.2 \%$ at $19 \mathrm{pmol}^{-1}$ and below $10 \%$ up to $180 \mathrm{pmol}$ $\mathrm{1}^{-1}$. The inter-assay coefficients of variation for 3 control samples were $25 \%\left(13 \mathrm{pmol}^{-1}\right), 6 \%$ $\left(39 \mathrm{pmol} \mathrm{l}^{-1}\right)$ and $10 \%\left(84 \mathrm{pmol}^{-1}\right)$. The lowest 
amount of oestradiol-17ß detectable (defined as the intercept of maximal binding - 2 SD) was $3 \mathrm{pmol} \mathrm{l}^{-1}$.

The plasma metabolite of $\mathrm{PGF}_{2 \alpha}, 15$-keto-dihydroprostaglandin $\mathrm{F}_{2 \alpha}$, was analyzed by RIA according to Kindahl et al. (1976). The intra-assay coefficients of variation for 2 control samples were $8.5 \%\left(240 \mathrm{pmol} \mathrm{l}^{-1}\right)$ and $4.2 \%$ $\left(485 \mathrm{pmol} \mathrm{l}^{-1}\right)$. The corresponding inter-assay coefficients of variation in 3 assays were $15.5 \%$ and $8.4 \%$, respectively. The practical detection limit of the assay was $30 \mathrm{pmol} \mathrm{l}^{-1}$.

LH was assayed by an RIA previously validated for use in bovine, ovine, and porcine plasma with minor modifications (Forsberg et al. 1993b). In brief, the assay utilized an anti-LH monoclonal antibody (MAB 518B7), equine LH (lot nr E263B) as standard and human ${ }^{125}$ I-LH (Diagnostic Products Corporation, Los Angeles, CA, USA) as tracer. Serial dilutions of llama and alpaca plasma produced displacement curves parallel to the equine standard curve. The intra-assay coefficient of variation was $37 \%$ at $1 \mu \mathrm{g} \mathrm{l}^{-1}, 15 \%$ at $4 \mu \mathrm{g} \mathrm{l}^{-1}$ and below $6 \%$ for concentrations up to $32 \mu \mathrm{g} \mathrm{l}^{-1}$. The interassay coefficients of variation for two control samples in four assays were $16 \%\left(2.2 \mu \mathrm{g} \mathrm{l}^{-1}\right)$ and $11.6 \%\left(18 \mu \mathrm{g} \mathrm{l}^{-1}\right)$. The lowest amount of LH detectable (defined as the intercept of maximal binding - 2 SD) was $0.8 \mu \mathrm{g} \mathrm{l}^{-1}$.

\section{Analysis of data}

A completely randomized analysis of variance was performed to detect differences in hormone concentrations. Since the oestradiol-17ß peak was not reached on the same day in all animals, the value on day 4 after mating was compared with the highest value obtained for each animal after mating. In the same way, in pregnant animals the highest progesterone concentration up until day 8 was compared with the lowest value registered between days 8 and 18 in each animal. A least significant difference test (LSD) was used to determine significant differences between means. Results are expressed as mean \pm s.e.m.

\section{Results}

Progesterone concentrations on day 12 after mating showed that 7 llamas and 8 alpacas were pregnant, 4 llamas and 4 alpacas had ovulated but not conceived and 2 llamas had not ovulated.

Progesterone concentrations in llamas, pregnant as well as non-pregnant, increased from $0.3 \pm 0.1 \mathrm{nmol} \mathrm{l}^{-1}$ on day 0 to $0.9 \pm 0.2$ on day 4 $(\mathrm{p}<0.05)$ and reached $12.1 \pm 1.0 \mathrm{nmol} \mathrm{l}^{-1}$ by day 8 ( $p<0.01)$ (Fig. $1 \mathrm{~b}$ and $1 \mathrm{e}$ ). In alpacas, a similar progesterone pattern was observed; however, the progesterone concentrations by day 4 were significantly higher than in llamas $(\mathrm{p}<0.05)$ : day $0=0.5 \pm 0.2 ;$ day $4=1.6 \pm 0.3$ $(\mathrm{p}<0.01)$ and day $8=11.7 \pm 1.2 \mathrm{nmol} \mathrm{l}^{-1}(\mathrm{p}$ $<0.01$ ) (Fig. $2 \mathrm{~b}$ and 2e). In non-pregnant animals, regardless of species, progesterone began to decrease by days 8-9 and had fallen below the detection limit of the assay by days 10-11 post mating ( $\mathrm{p}<0.01)$ (Fig. $1 \mathrm{~b}$ and $2 \mathrm{~b}$ ).

A transient decrease in progesterone concentrations was observed in pregnant llamas ( $p<$ $0.05)$ and alpacas $(\mathrm{p}<0.01)$ between days 8 and 18. This drop in circulating progesterone concentrations started at the same time that progesterone began to decrease in non-pregnant animals. Inserts in Fig. 1e and 2e show representative patterns of progesterone secretion in a pregnant llama and a pregnant alpaca.

High concentrations of the prostaglandin metabolite, $709 \pm 60$ in llamas and $375 \pm 30$ pmol $1^{-1}$ in alpacas, were registered immediately after mating. By day 4, concentrations had declined to around $250 \mathrm{pmol} \mathrm{l}^{-1}$ in llamas and $150 \mathrm{pmol}$ $\mathrm{1}^{-1}$ in alpacas $(\mathrm{p}<0.01)$. In non-pregnant animals, a rise in prostaglandin secretion was observed from days 9 to $12(\mathrm{p}<0.01)$. The highest 

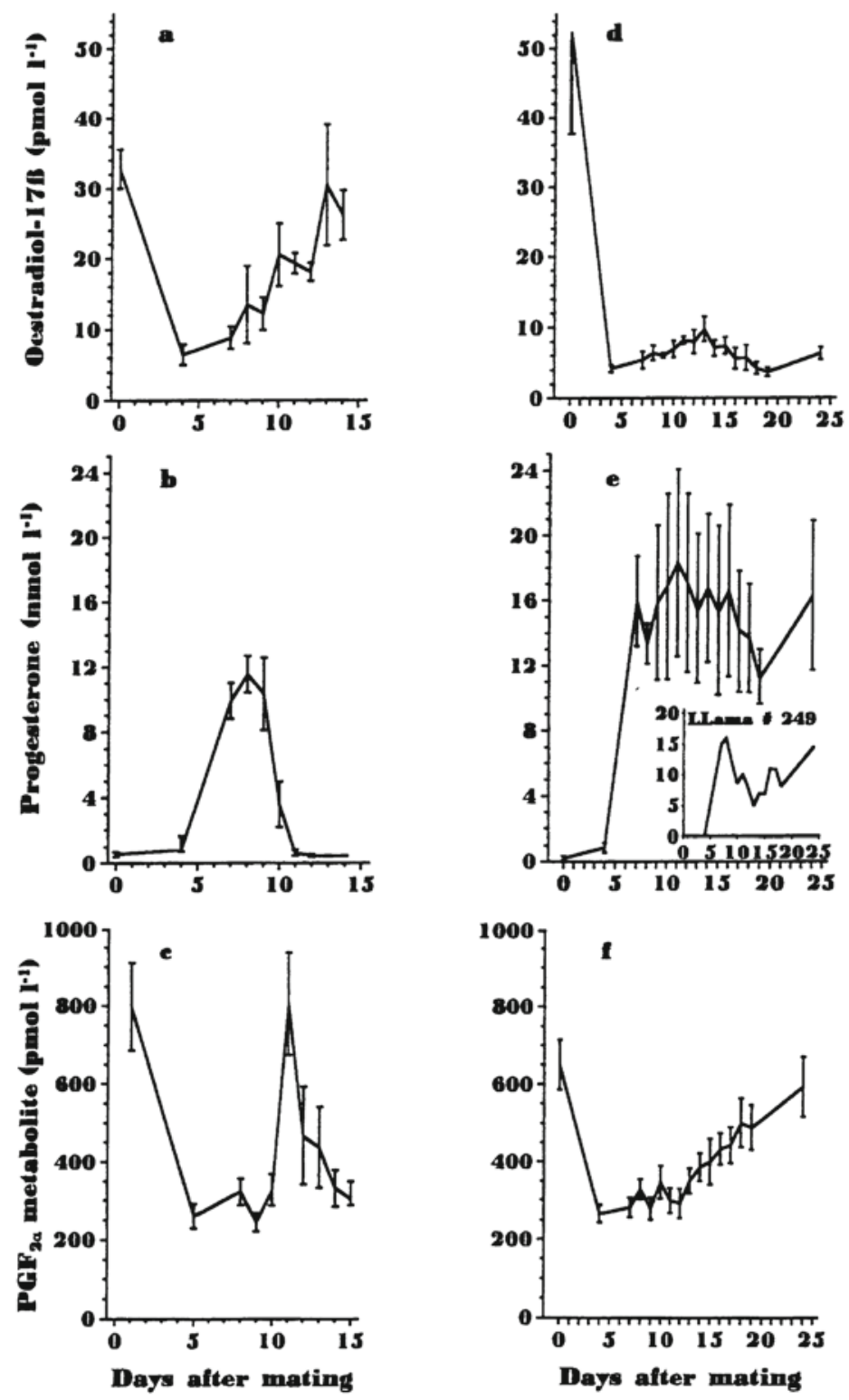

(Non-pregnant)

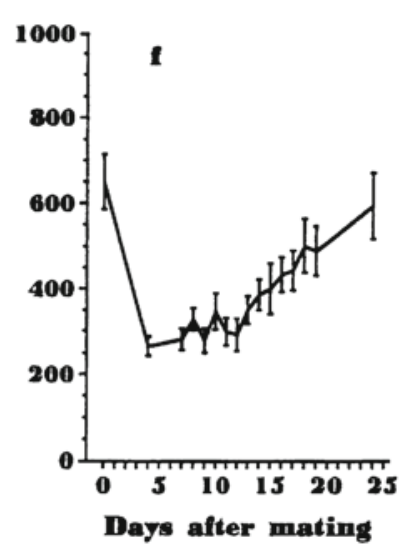

(Pregnant)

Figure 1: Concentrations of plasma oestradiol-17ß, progesterone and 15 -keto-dihydro- $\mathrm{PGF}_{2 \alpha}$ in non-pregnant llamas during the first 14 days after mating (a,b, and c) and in pregnant llamas during the first 24 days (d, e, f, ) after mating (mean \pm s.e.m). The insert in Fig. e depicts the progesterone profile in a representative llama, showing the drop in progesterone between days 8 and 18 . 

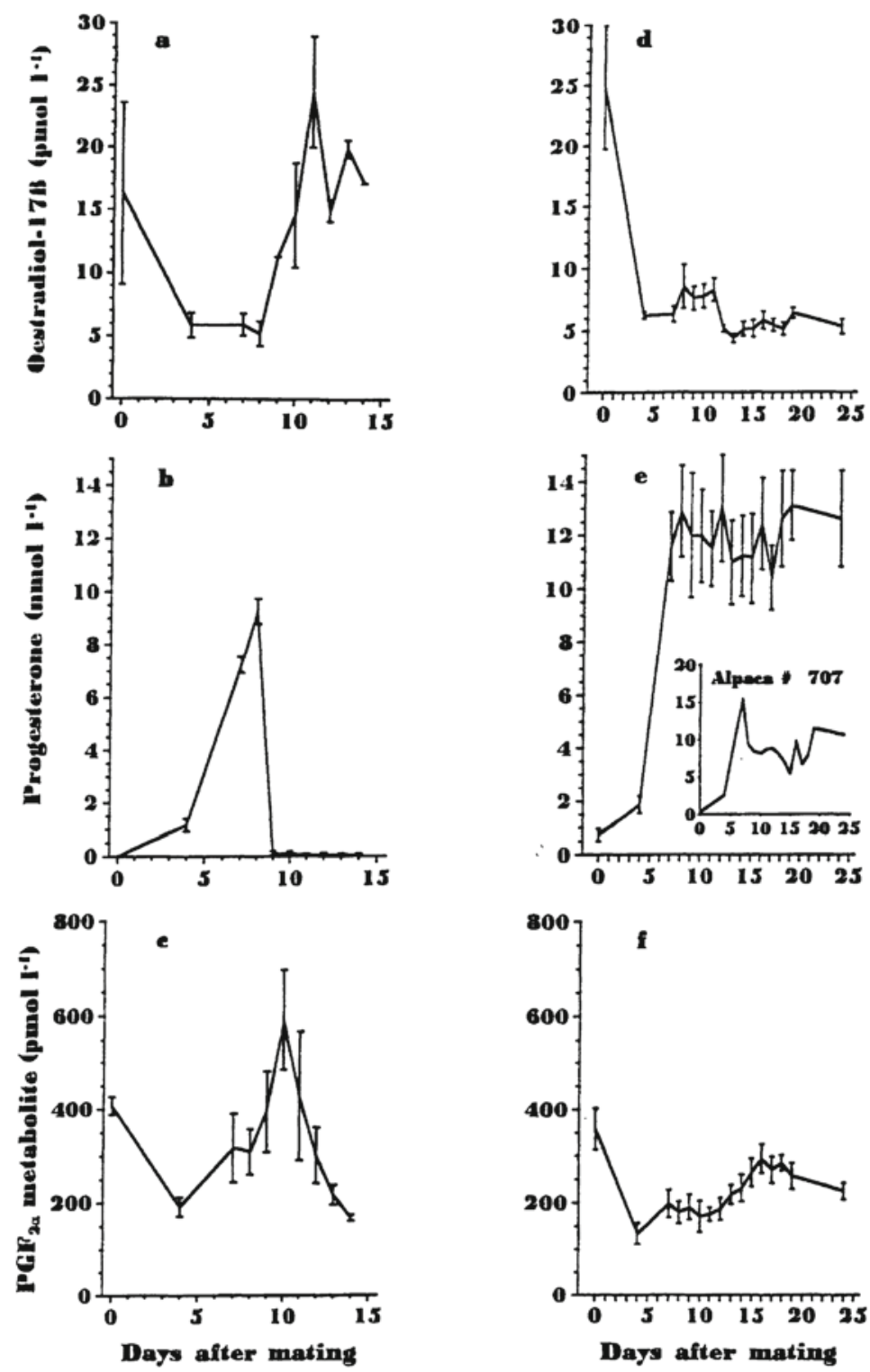

(Non-pregnant)

(Pregnant)

Figure 2: Concentrations of plasma oestradiol-17ß, progesterone and 15-keto-dihydro- $\mathrm{PGF}_{2 \alpha}$ in non-pregnant alpacas during the first 14 days after mating $(a, b$, and $c)$ and in pregnant alpacas during the first 24 days $(\mathrm{d}, \mathrm{e}$, f,) after mating (mean \pm s.e.m). The insert in Fig. e depicts the progesterone profile in a representative alpaca, showing the drop in progesterone between days 8 and 18 . 


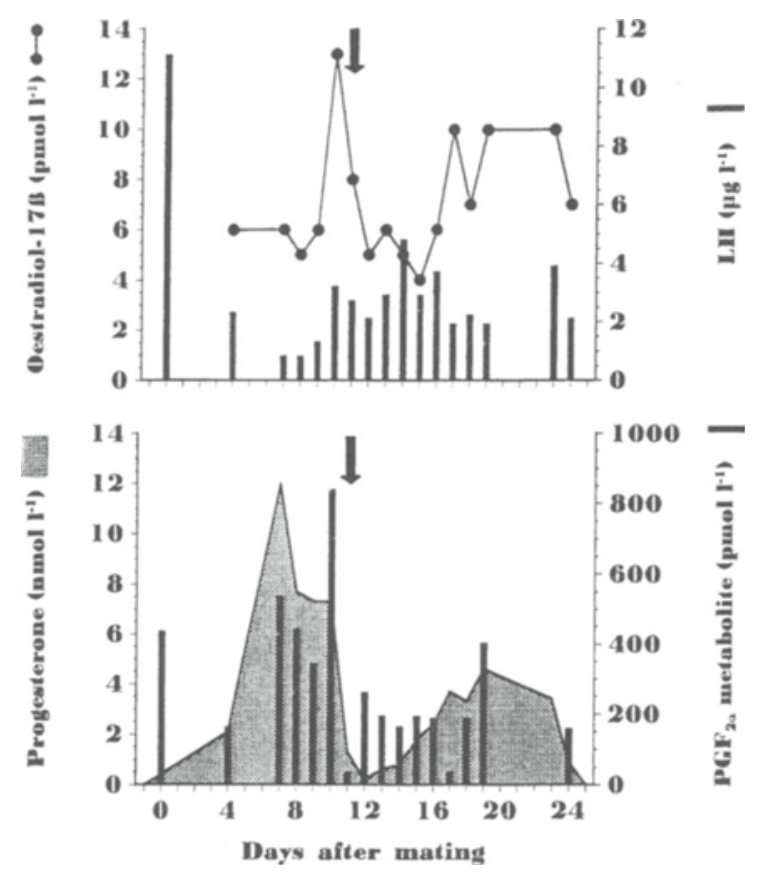

Figure 3: Hormonal patterns in one non-pregnant alpaca (no. 708). Since there were no records of contact with a male after mating on day 0 , the profile suggests that the animal had a spontaneous ovulation around day 11 after mating (arrow). Note the temporal relationship between the $\mathrm{PGF}_{2 \alpha}$ release terminating the first luteal phase, the increase in $\mathrm{LH}$ concentration, the decline in oestradiol-17ß and the subsequent rise in progesterone secretion.

values were $805 \pm 131 \mathrm{pmol} \mathrm{l}^{-1}$ in llamas and $591 \pm 106$ pmol l$^{-1}$ in alpacas. In pregnant animals, no prostaglandin peaks were registered during this period, but values slowly increased, reaching concentrations on day 24 that were considerably higher than those registered on day $4(\mathrm{p}<0.01)$.

Oestradiol-17ß concentrations on the day of mating were high in both species: $46 \pm 10$ (range 19 to 108) in llamas and $23 \pm 4$ (9 to 54) pmol $1^{-1}$ in alpacas (Fig. 1a and d, Fig. 2a and d). On day 4, oestradiol concentrations had decreased close to the detection limit of the assay in all groups $\left(6 \pm 0.4 \mathrm{pmol} \mathrm{l}^{-1}\right)$ and remained low until day 7 . From day 8 the pattern of oestradiol secretion varied depending on whether or not the animals were pregnant $(\mathrm{p}<0.01)$. In the pregnant group, oestradiol $17-\beta$ peaked between days 11 and 13 in llamas $(11 \pm 2$ pmol $\left.1^{-1}\right)$ and between days 9 and 11 in alpacas $(10 \pm$ 1 pmol $^{-1}$ ), whereupon concentrations declined, reaching low levels by day 19 in llamas and by day 13 in alpacas. Even though peak values did not occur on the same day in all animals, they were significantly higher than those recorded on day 4 in both llamas $(\mathrm{p}<0.01)$ and alpacas $(\mathrm{p}<0.01)$. The interval between the first increase in oestradiol concentration and the next minimum value was 11 days in pregnant llamas and 5 days in pregnant alpacas (Fig. 1d and 2d). In non-pregnant animals oestradiol-17ß secretion increased on day 8 , reaching peak concen- 


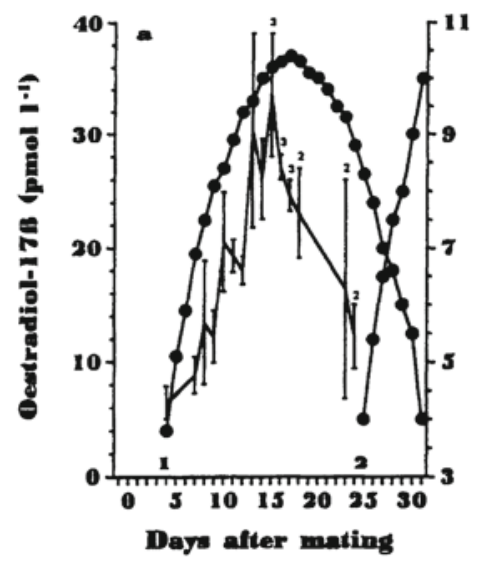

(Non-pregnant)

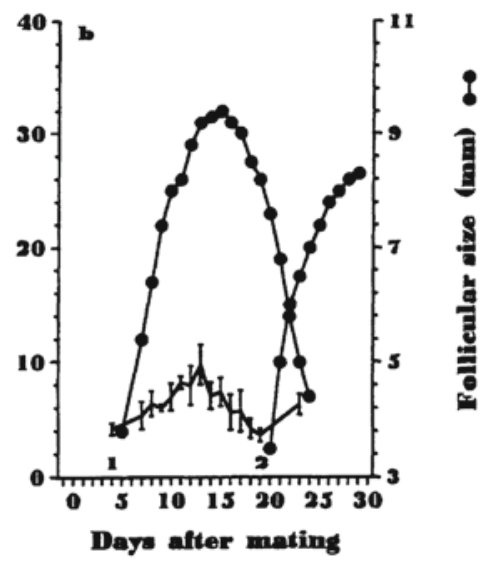

(Pregnant)

Figure 4: Peripheral blood concentrations of oestradiol-17 $B$ and follicular size after mating in non-pregnant (a) and pregnant (b) llamas. Follicular size redrawn after Adams et al. (1990) by permission from Journal of Reproduction and Fertility. 1 = beginning of the first follicular wave; 2 = beginning of the second follicular wave after mating. In non-pregnant animals, numerals after day 14 indicate number of animals, and bars after day 18 indicate range.

trations on days $13-14(\mathrm{p}<0.01)$ in llamas and on day $11(\mathrm{p}<0.01)$ in alpacas. The mean peak value was higher in the non-pregnant animals ( $30 \pm 5$ pmol $^{-1}$ in llamas and $24 \pm 5$ in alpacas) than in the pregnant ones $\left(11 \pm 2\right.$ pmol $^{-1}$ in llamas and $10 \pm 1$ pmol $1-1$ in alpacas $)(\mathrm{p}<0.01)$. Only two non-pregnant llamas and one alpaca were under study on day 19 when oestradiol$17 ß$ was still high in llamas (range 19.1 - 27.0 $\mathrm{pmol} \mathrm{l}^{-1}$ ) and had reached low concentrations in the alpaca. Furthermore, in the samples obtained on day 24 after mating, oestradiol-17ß concentrations were still high in llamas and had started to increase again in the alpaca.

$\mathrm{LH}$ was high in both llamas $\left(2.6 \pm 0.6 \mu \mathrm{g}^{-1} ; \mathrm{n}\right.$ $=8)$ and alpacas $\left(3.6 \pm 0.9 \mathrm{mg} \mathrm{l}^{-1} ; \mathrm{n}=11\right)$ in the sample obtained on the day of mating. No difference in LH secretion was detected between the non-pregnant and pregnant groups. By day 4 , values had declined to just above the detection limit of the assay and remained at this level, although there were slight increases in some animals until the end of the study. The post-copulatory increase in LH was not detected in one llama and 3 alpacas.

Although no contact with a male was registered during the period after mating, a strange progesterone profile was observed in a non-pregnant alpaca (Fig. 3). Therefore, data from this animal were excluded from the statistical analysis. This alpaca had a normal pattern of progesterone secretion until day 12 when she was classified as non-pregnant. LH concentrations increased after day 11 . Thereafter, progesterone started to rise on day 15 and remained high for 9 days, indicating luteal activity. Oestradiol$17 \beta$ concentrations had sharply declined to baseline values by days 10 to 12 after mating. Another increase in oestradiol-17ß was observed after day 15 . This increase lasted until day 24, when LH concentrations had started to increase once more. 


\section{Discussion}

The high oestradiol-17ß concentrations recorded on the day of mating are in agreement with previous reports. However, values are higher than those reported by Bravo et al. (1990b) and lower than those described by $\mathrm{Su}$ mar et al. (1988). The low oestradiol-17ß concentrations recorded on day 4 , which was associated with increased concentrations of progesterone, indicated that ovulation had occurred which was confirmed by laparoscopy.

A positive correlation between oestradiol-17ß concentrations and follicular size in non pregnant llamas has been reported previously (Bravo et al. 1990a). However, to our knowledge this is the first report describing a consistent pattern of oestradiol-17ß secretion in pregnant llamas and alpacas during the first weeks post mating. Bravo et al. (1990) and Leon et al. (1990) reported unchanged concentrations of oestradiol-17ß in llamas during the first 10 and 35 days after mating with an intact male, respectively.

In non-pregnant animals the highest post-mating concentrations of oestradiol-17ß were recorded after the drop in progesterone, and the peak was attained after luteolysis. No significant differences were detected in non-pregnant llamas and alpacas between peak concentrations of oestradiol-17ß attained during the first follicular wave after mating and those recorded on day $0(p=0.08)$. Furthermore, oestradiol$17 ß$ peak values were, on average, 3 -fold higher in non-pregnant animals than in pregnant ones at the same time, suggesting a negative influence of progesterone produced by the corpus luteum on follicular activity and subsequent oestradiol-17ß release. Adams et al. (1990) claimed that the presence of a corpus luteum in llamas was associated with a depressed number of follicles and reduced prominence of dominant follicles. They also reported that successive dominant follicles emerged at intervals of
19.8 days in unmated and sterile-mated animals as compared with 14.8 days in pregnant ones. Maximum diameters of anovulatory dominant follicles were also greater in non-pregnant llamas than in pregnant ones. In Fig. $4 \mathrm{a}$ and $4 \mathrm{~b}$ the oestradiol-17ß profiles registered in this study for llamas (non-pregnant and pregnant respectively) are compared with the follicular dynamics described by Adams et al. (1990) using ultrasound technique. The figures illustrate the close relationship between follicular activity and oestradiol-17ß secretion, giving further support to the suggestion that progesterone exerts a negative influence on follicular activity in pregnant animals by reducing follicular oestradiol-17ß production, thereby shortening the duration of follicular waves.

The increased LH secretion noted immediately after copulation is in agreement with results previously reported by Bravo et al. (1992). The failure to detect the LH peak in 4 of the animals that ovulated, as confirmed by laparoscopy and increased progesterone secretion, was most likely a consequence of the sampling schedule. The disclosure that 2 animals failed to ovulate in response to the mating stimulus ( $8 \%$ ) is in accordance with previous reports (Smith et al. 1994).

The high concentrations of prostaglandin metabolite immediately after mating in both species were unexpected. Sumar et al. (1988), using a similar sampling schedule, could not detect high prostaglandin metabolite concentrations on the day of mating in llamas and alpacas mated with vasectomised males. Even though the results are contradictory, one cannot exclude the possibility that the high levels recorded after mating in our study could have been a consequence of the mating stimulus per se. More detailed studies with timed mating and blood sampling at short intervals are required to further elucidate the phenomenon.

The increased progesterone concentrations ob- 
served on day 4 after mating in all groups agree with the observation that the corpus luteum can be detected by ultrasound on day 3 post ovulation, corresponding to day 5 after mating (Adams et al. 1990). Since that was the first sample collected after the day of mating, any previous increase could have been missed. However, previous studies, using more frequent sampling schedules, have reported the first increase in progesterone concentrations to occur on day 5 after mating (Sumar et al. 1988) and day 4 after ovulation (Adams et al. 1991). In non-pregnant animals, progesterone decreased between days 8 and 11 , coincident with a massive release of $\mathrm{PGF}_{2 \alpha}$, thereby lending further support to the suggestion that prostaglandin from the uterus is the luteolytic factor in llamas and alpacas (Sumar et al. 1988).

Previous investigations have estimated the luteal phase in llamas and alpacas to last between 6 and 10 days (Sumar et al. 1988, Adams et al. 1990, Adams et al. 1991, Bravo et al. 1991a). Ovulation is estimated to occur 24 to $26 \mathrm{~h}$ after mating in alpacas and after 44 to $48 \mathrm{~h}$ in llamas (San-Martin et al. 1968, Fernadez-Baca et al. 1970, Adams et al. 1990, Bravo et al. 1990b). Combining these results with our own gives a realistic estimate of the corpus luteum lifespan of around 8 - 9 days in both species.

In the pregnant animals a temporary decline in progesterone was observed between days 8 and 18 which agrees with previous reports (Adams et al. 1991). The resurgence of progesterone and the rescue of the corpus luteum suggests that in this period of gestation a signal produced by the blastocyst is responsible for the maternal recognition of pregnancy. No dramatic bursts in prostaglandin release were observed in connection with the decline in progesterone concentrations. However, any changes in prostaglandin secretion during this period could have been missed owing to the low sampling frequency blood sampling was far too infrequent to detect subtle changes in prostaglandin release. Preliminary results from an experiment with more frequent blood sampling between days 8 and 15 have revealed an increase in the release of prostaglandin in pregnant animals during this period ( $A b a$ et al. unpublished results).

The divergent endocrine patterns observed in one alpaca were probably the consequence of a spontaneous ovulation around day 11 after mating. The frequency of spontaneous ovulations has been reported to range from 4 to $10 \%$ (Smith et al. 1994). The subsequent progesterone secretion showed that the corpus luteum had a normal lifespan.

\section{Acknowledgements}

We thank Dr. J. Roser and Dr. H. Papkoff for supplying the $\mathrm{LH}$ antiserum and the equine $\mathrm{LH}$ standard. The Swedish Agency for Research in Developing Countries (SAREC), Swedish International Development Agency (SIDA) and Department of Physiopathology, Faculty of Veterinary Sciences, UNCPBA, Tandil, Argentina, are acknowledged for financial support.

\section{References}

Adams GP, Sumar J, and Ginther OJ: Effects of lactational and reproductive status on ovarian follicular waves in llamas (Lama glama). J. Reprod. Fert., 1990, 90, 535-545.

Adams GP, Sumar J and Ginther OJ: Form and function of the corpus luteum in llamas. Anim. Reprod. Sci., 1991, 24, 128-138.

Bravo PW, Fowler ME, Stabenfeldt GH and Lasley $B L$ : Ovarian follicular dynamics in the llama. Biol. Reprod., 1990a, 43, 579-585.

Bravo PW, Fowler ME, Stabenfeldt GH and Lasley $B L$ : Endocrine responses in the llama to copulation. Theriogenology, 1990b, 33, 891-899.

Bravo PW, Stabenfeldt GH, Fowler ME and Lasley $B L$ : Urinary steroids in the periparturient and postpartum periods through pregnancy in llamas. Theriogenology, 1991b, 36, 267-278.

Bravo PW, Stabenfeldt GH, Fowler ME and Lasley $B L$ : Pituitary response to repeated copulation and/or gonadotropin-releasing hormone administration in llamas and alpacas. Biol. Reprod., $1992,47,884-888$. 
Bravo PW, Stabenfeldt GH, Lasley BL and Fowler $M E$ : The effect of ovarian follicle size on pituitary and ovarian responses to copulation in domesticated South American Camelids. Biol. Reprod., 1991a, 45, 553-559.

Bravo PW, Sumar J: Laparoscopic examination of the ovarian activity in alpacas. Anim. Reprod. Sci., 1989, 21, 271-281.

Fernandez-Baca S, Madden HL, and Novoa C: Effect of different mating stimuli on ovulation in the alpaca. J. Reprod. Fert., 1970, 22, 261-267.

Forsberg M, Linde-Forsberg C, Karlsson A, Carlsson $M-A$ : Progesterone and oestradiol in canine plasma monitored by enhanced luminescence immunoassays. J. Reprod. Fert., 1993a, Suppl 47, 127-132.

Forsberg M, Tagle R, Madej A, Molina JR and Carlsson $M-A$ : Radioimmunoassay of bovine, ovine and porcine luteinizing hormone with a monoclonal antibody and a human tracer. Acta vet. Scand., 1993b, 34, 255-262.

Kindahl H, Edqvist LE, Granström $E$ and Bane A: The release of prostaglandin $\mathrm{F}_{2 \alpha}$ as reflected by 15-keto-13,14-dihydroprostaglandin $F_{2 \alpha}$ in the peripheral circulation during normal luteolysis in heifers. Prostaglandins, 1976, 11, 871-878.

Leon JB, Smith BB, Timm KI and LeCren G: Endocrine changes during pregnancy, parturition and the early post-partum period in the llama (Lama glama). J. Reprod. Fert., 1990, 88, 503-511.

Novoa C: Reproduction in camelidae (a review). J. Reprod. Fert., 1970, 22, 3-20.

Pierson RA and Ginther OJ: Follicular population dynamics during estrus cycle of the mare. Anim. Reprod. Sci., 1987, 14, 219-231.

Pollard JC, Littlejohn RP and Scott IC: The effects of mating on the sexual receptivity of females alpacas. Anim. Reprod. Sci., 1994, 34, 289-297.

San-Martin M, Copaira M, Zunigra J, Rodriguez R, Bustinza $G$ and Acosta L: Aspects of reproduction in the alpaca. J. Reprod. Fert., 1968, 16, 395399.

Savio JD, Keenan L, Boland MP and Roche JF: Pattern of growth of dominant follicles during the oestrous cycle in heifers. J. Reprod. Fert., 1988, 83, 663-671.

Sirois $J$ and Fortune JE: Lengthening the bovine estrous cycle with low levels of progesterone: a model for studing ovarian follicular dominance. Endocrinology, 1990, 127, 916-924.

Smith CL, Peter AT and Pugh DG: Reproduction in llamas and alpacas: a review. Theriogenology, 1994, 41, 573-592.

Sumar J, Fredriksson G, Alarcón V, Kindahl $H$ and Edqvist LE: Levels of 15-keto-13,14-dihydro$\mathrm{PGF}_{2 \alpha}$, progesterone and oestradiol-17 $\beta$ after induced ovulations in llamas and alpacas Acta vet. Scand., 1988, 29, 339-346.

\section{Sammanfattning}

Hormonelle förändringar efter befadening hos dräktiga och icke drägtiga lamor och alpakor

Plasma koncentrationerna av östradiol-17ß, progesteron, 15-keto-dihydro- PGF $_{2 \alpha}$ och luteiniserande hormon (LH) analyserades hos lamor (13) och alpackor (12) efter betäckning. Koncentrationena av LH och PGF2ametaboliten var höga omedelbart efter betäckning. Ägglossning skedde i $92 \%$ av fallen. Den första signifikanta ökningen av progesteron kunde registreras 4 dagar efter betäckning. Hos de djur som inte blev dräktiga gick gulkroppen i regression efter 8-9 dagar, vilket sammanföll med en hög sekretion av prostaglandin. Hos de djur som blev dräktiga registrerades en övergående sänkning i progesteronnivån mellan dag 8 till 18 hos båda djurslagen som inte kunde relateras till en ökad prostaglandinfrisättning. Nivån av östradiol-17ß var hög på betäckningsdagen, sjönk till låga värden dag 4 och ökade sedan på dag 8 hos såväl dräktiga som icke dräktiga djur. De högsta nivåerna registrerades hos icke dräktiga djur efter det att gulkroppen hade försvunnit. Nivåerna var också höga under en längre tid hos icke dräktiga djur. Resultaten tyder på att progesteron från gulkroppen undertrycker follikelutvecklingen hos dräktiga djur vilket avspeglar sig i låga mätbara östradiol-17ß nivåer i blod.

(Received May 10, 1995; accepted June 22, 1995).

Reprints may be obtained from: M.A. Aba, Department of Clinical Chemistry, Faculty of Veterinary Medicine, Swedish University of Agricultural Sciences, P.O. Box 7038, S-750 07, Uppsala, Sweden. 